\title{
Między USA a Chinami: Wizje pozycji Japonii w systemie międzynarodowym
}

\section{Wprowadzenie}

Celem niniejszego artykułu jest ukazanie ewolucji i systematyzacja różnych opinii istniejących $\mathrm{w}$ japońskim świecie polityki na temat miejsca Japonii $\mathrm{w}$ regionalnym i globalnym układzie sił. Zostały zanalizowane zwłaszcza trzy stanowiska reprezentowane przez: umiarkowane skrzydło Partii Liberalno-Demokratycznej (PL-D), środowisko Ozawy Ichirō i Hatoyamy Yukio w Partii Demokratycznej (PD) oraz obóz nacjonalistyczny w PL-D na czele z premierem Abe Shinzō. Każde z nich proponowało odmienną wizję miejsca Japonii w porządku międzynarodowym: jako tradycyjnego sojusznika USA, który jednocześnie dąży do pojednania z Chinami, jako samodzielnego podmiotu zmierzającego do zbliżenia z ChRL kosztem relacji ze Stanami Zjednoczonymi lub jako aktywnego gracza na polu polityki bezpieczeństwa, utrzymującego ścisłe przymierze z USA w celu równoważenia potęgi Chin.

Analiza opiera się na zbadaniu poglądów zawartych w książkach programowych i pamiętnikach kluczowych decydentów, zwłaszcza premierów. Pomocniczym źródłem informacji były wywiady z japońskimi parlamentarzystami. Na tle deklaracji poszczególnych przywódców politycznych zanalizowane zostały także przykłady decyzji podjętych przez nich w celu modyfikacji pozycji międzynarodowej Japonii wobec Stanów Zjednoczonych i Chin. Ponieważ artykuł skupia się na badaniu poglądów politycznych najbardziej wpływowych osób w rządzie, pominięte zostały opinie reprezentowane przez ugrupowania opozycyjne. Różnorodność podejść japońskich polityków konserwatywnych do polaryzacji na linii Pekin-Waszyngton 
ukazuje dylemat, przed którym stoją władze w Tokio w obliczu dynamicznych zmian zachodzących na arenie międzynarodowej. Jest także dowodem na wyjątkową stałość ideologiczną trzech głównych nurtów zanalizowanych w artykule ${ }^{1}$.

\section{Różne wizje pozycji Japonii wobec USA i ChRL w okresie zimnej wojny}

W celu omówienia obecnego nastawienia japońskich polityków do Chin i USA warto jest dokonać analizy głównych nurtów w polityce zagranicznej Japonii w okresie zimnowojennym. Jest to związane z tym, że najbardziej wpływowi decydenci w japońskim rządzie w ostatnich latach nie tylko wywodzili się $\mathrm{z}$ odmiennych frakcji w PL-D, które zostały założone w czasie zimnej wojny, ale również często jako potomkowie premierów z lat 50. i 60. $\mathrm{XX}$ wieku deklarowali potrzebę kontynuacji linii politycznej swoich wielkich przodków.

W wyniku przegranej II wojny światowej Japonia znalazła się pod amerykańską okupacją. Tuż po podpisaniu traktatu pokojowego z San Francisco w 1951 roku władze w Tokio musiały zawrzeć nierównorzędny traktat sojuszniczy z USA. Chociaż żadna z japońskich partii konserwatywnych nie negowała wówczas potrzeby utrzymania bliskich relacji z rządem w Waszyngtonie, $\mathrm{z}$ czasem uformowały się $\mathrm{w}$ tym środowisku trzy wizje sojuszu ze Stanami Zjednoczonymi. O ile premier Yoshida Shigeru (1946-1947, 1948-1954) uznał parasol bezpieczeństwa zapewniony przez USA za kluczowy czynnik umożliwiający skupienie się na wzroście gospodarczym, o tyle premier Hatoyama Ichirō (1954-1956) optował za większą równorzędnością Japonii w kontaktach ze Stanami Zjednoczonymi. Co ciekawe, zarówno reprezentanci nurtu Yoshidy, jak i szkoły Hatoyamy dostrzegali potrzebę nawiązania konstruktywnego dialogu z ChRL - pierwsi głównie w nadziei na korzyści gospodarcze, zaś drudzy przede wszystkim w celu demonstracji niezależności od USA w polityce zagranicznej. Nieco odmienne stanowisko wykazywał premier Kishi Nobusuke (1957-1960), który reprezentował skrajnie antykomunistyczne i protajwańskie skrzydło w PL-D. Z tego powodu łączył

1 Niniejszy artykuł powstał $\mathrm{w}$ ramach projektu badawczego Zmiany instytucjonalne w polityce zagranicznej Japonii po reformie rzadu centralnego na poczatku XXI wieku. Projekt został sfinansowany ze środków Narodowego Centrum Nauki przyznanych na podstawie decyzji numer DEC-2013/11/B/HS5/04005. W 2017 roku autor otrzymał Nagrodę Naukową Fundacji Uniwersytetu Łódzkiego. 
wyraźnie proamerykańską orientację z chęcią zachowania dystansu wobec Chin kontynentalnych.

Premier Yoshida zdecydowanie krytykował japońską lewicę, która uważała, że Japonia powinna zachować neutralność w zimnowojennej konfrontacji między Stanami Zjednoczonymi a Związkiem Radzieckim. Twierdził, iż o ile rząd w Tokio musi bronić pacyfistycznej konstytucji, która umożliwiała skupienie się na rozwoju gospodarczym zamiast remilitaryzacji, o tyle prawdziwa neutralność była zwykłą iluzją. Według Yoshidy, zdecydowane opowiedzenie się po stronie Stanów Zjednoczonych nie tylko zapewniało Japonii ochronę przed napaścią z zewnątrz, ale również było podstawą globalnej równowagi sił między dwoma biegunami zimnej wojny. Jak przekonywał, deklaracja neutralności przez Japonię zaburzyłaby ową równowagę na korzyść obozu komunistycznego. Z tej perspektywy Yoshida postrzegał również relacje z Chinami. Nie wykluczał normalizacji oficjalnych stosunków dyplomatycznych z ChRL w przyszłości, ale uzależniał taką decyzję od polityki Stanów Zjednoczonych. W przeciwnym wypadku, według Yoshidy, przeniesienie uznania międzynarodowego $\mathrm{z}$ władz w Tajpej na rząd w Pekinie zaburzyłoby delikatną równowagę sił w zimnowojennej konfrontacji² Zasadniczo jednak Yoshida uważał, że zamiast traktować Chiny kontynentalne jak wroga, należy je jak najszybciej odciągnąć od obozu sowieckiego ${ }^{3}$. Następcy Yoshidy kontynuowali tę pragmatyczną, umiarkowaną politykę. Nie jest przypadkiem, że to wywodzący się z nurtu Yoshidy premier Tanaka Kakuei i minister spraw zagranicznych Ōhira Masayoshi zadecydowali o normalizacji relacji dyplomatycznych z ChRL w 1972 roku, zaledwie rok po „szoku Nixona”4. Od tamtej pory środowisko dawnego obozu Yoshidy w PL-D stało się głównym promotorem przyjaźni chińsko-japońskiej.

Odmienną wizję miejsca Japonii w systemie międzynarodowym reprezentował Hatoyama Ichirō. Mimo że w 1946 roku był liderem zwycięskiej Japońskiej Partii Liberalnej, tuż po wyborach parlamentarnych został pozbawiony przez Amerykanów prawa do piastowania urzędów publicznych. Te personalne uwarunkowania częściowo tłumaczą, dlaczego gdy tylko Hatoyama powrócił do polityki po odzyskaniu przez Japonię niepodległości w 1952 roku, zaczął nawoływać do zniesienia nadmiernej, jego zdaniem,

S. Yoshida, Sekai to Nihon [Świat a Japonia], Tokio 1963, s. 128-147.

3 Idem, Kaisō jūnen [Wspomnienia z 10 lat], t. 1, Tokio 1998, s. 227.

4 W lipcu 1971 roku prezydent USA Richard Nixon ogłosił plan odwiedzenia Chin, czego rzeczywiście dokonał w lutym 1972 roku. Ta nagła deklaracja była zaskoczeniem dla japońskich decydentów. 
podległości władz w Tokio wobec USA. Jak argumentował, Japonia powinna posiadać normalną armię i zabezpieczyć się przed uwikłaniem w ewentualną wojnę z blokiem komunistycznym poprzez jak najszybszą normalizację stosunków dyplomatycznych ze Związkiem Radzieckim ${ }^{5}$. Rzeczywiście, jako premier Hatoyama zdołał nawiązać oficjalne relacje dyplomatyczne z rządem w Moskwie w 1956 roku. W trakcie swojej kadencji próbował również rozpocząć dialog z komunistycznymi Chinami, m.in. popierając wymianę handlową $\mathrm{z}$ tym krajem ${ }^{6}$. Hatoyama nie był jednak w stanie przezwyciężyć podziałów zimnowojennych i musiał ograniczyć wszelkie kontakty z ChRL do ściśle nieoficjalnego wymiaru.

Tabela 1. Stanowiska japońskich polityków konserwatywnych na temat relacji z USA i ChRL

\begin{tabular}{|l|l|l|}
\cline { 2 - 3 } \multicolumn{1}{c|}{} & Luźny sojusz z USA & Ścisły sojusz z USA \\
\hline \multirow{2}{*}{$\begin{array}{l}\text { Chiny jako } \\
\text { partner }\end{array}$} & $\begin{array}{l}\text { Proazjatycki multilateralizm } \\
\text { Hatoyama Ichirō } \\
\text { Hatoyama Yukio } \\
\text { Ozawa Ichirō (po 2003) }\end{array}$ & $\begin{array}{l}\text { Proamerykański liberalizm } \\
\text { Yoshida Shigeru } \\
\text { Kōno Yōhei } \\
\text { Nonaka Hiromu }\end{array}$ \\
\hline $\begin{array}{l}\text { Chiny jako } \\
\text { zagrożenie }\end{array}$ & $\begin{array}{l}\text { Multilateralizm w ramach ONZ } \\
\text { Ozawa Ichirō (do 2003 roku) }\end{array}$ & $\begin{array}{l}\text { Proamerykański nacjonalizm } \\
\text { Kishi Nobusuke } \\
\text { Abe Shinzō }\end{array}$ \\
\hline
\end{tabular}

Źródło: opracowanie własne.

Trzecie stanowisko na temat usytuowania Japonii pomiędzy USA a ChRL w okresie zimnowojennym reprezentował Kishi Nobusuke, dziadek obecnego premiera Abe Shinzō. Podobnie jak Hatoyama, Kishi był zwolennikiem zwrotu ku bardziej równorzędnym relacjom ze Stanami Zjednoczonymi. Rzeczywiście, zdołał przekonać rząd w Waszyngtonie do rewizji traktatu sojuszniczego w 1960 roku. Przeciwnie jednak niż Hatoyama, Kishi postrzegał Japonię jednoznacznie jako członka obozu antykomunistycznego. Podkreślał, że Japonia powinna razem z USA być współodpowiedzialna za utrzymanie pokoju i bezpieczeństwa w regionie zachodniego Pacyfiku. Kishi uważał, iż to właśnie „wieczna przyjaźń” i współpraca obu krajów stanowiła kluczowy czynnik dla utrzymania stabilności Azji Wschodniej. Chociaż proamerykanizm Kishiego współgrał z linią dyplomatyczną Yoshidy, był oparty na innych przesłankach, zwłaszcza na silnych przekonaniach antykomunistycznych.

5 I. Hatoyama, Hatoyama Ichirō kaikoroku [Pamiętnik Hatoyamy Ichirō], Tokio 1957, s. 116-117.

6 D. Liu, Toki wa nagarete - Nitchū kankei hishi gojūnen [Czas przemija - 50 lat sekretnej historii stosunków japońsko-chińskich], t. 1, Tokio 2002, s. 110-145. 
W tym kontekście nie dziwi, iż Kishi miał zupełnie odmienne zdanie na temat relacji z ChRL. Wyraźnie wspierał reżim Guomindangu na Tajwanie, zaś Chiny traktował niczym poważne zagrożenie dla „wolnego świata”.

Tabela 1 obrazuje trzy powyższe wizje roli, jaką Japonia powinna odgrywać w trójkącie ze Stanami Zjednoczonymi i Chinami, oraz ich głównych przedstawicieli. Idee reprezentowane przez szkołę Yoshidy można nazwać proamerykańskim liberalizmem, poglądy grupy Hatoyamy proazjatyckim multilateralizmem, zaś koncepcje polityki zagranicznej głoszone przez Kishiego i jego następców proamerykańskim nacjonalizmem. Wszystkie trzy nurty nadal występują $\mathrm{w}$ dwóch największych japońskich ugrupowaniach - PL-D i PD. Najrzadziej reprezentowaną opcją pośród japońskich polityków konserwatywnych było postrzeganie Chin jako zagrożenie przy jednoczesnej chęci zachowania tylko luźnego sojuszu z USA. Poglądy najbliższe owemu stanowisku głosił Ozawa Ichirō, który był głównym decydentem stojącym za rządami Hosokawy Morihiro (1993-1994) i Haty Tsutomu (1994). Opcję tę można nazwać multilateralizmem w ramach ONZ. Kolejne sekcje artykułu analizują ewolucję wyżej wymienionych nurtów po zimnej wojnie, z naciskiem na okres po alternacji władzy w Japonii w 2009 roku.

\section{Próba zwrotu ku „trójkątowi równobocznemu”}

We wrześniu 2009 roku rządy w Japonii objęła PD. Dwóch liderów owego ugrupowania, przewodniczący partii i nowy premier Hatoyama Yukio oraz sekretarz generalny Ozawa Ichirō, postulowali redefinicję pozycji Japonii w relacjach ze Stanami Zjednoczonymi i Chinami. Zupełnie jak przed laty premier Hatoyama Ichirō, jego wnuk podkreślał, że rząd w Tokio nie powinien być całkowicie zależny od władz w Waszyngtonie. W przeciwieństwie do sytuacji z lat 50. XX wieku jednak, Hatoyama Yukio nie był ograniczany w swoich dążeniach podziałami zimnowojennymi. $Z$ tego powodu zdawało się, że nawiązanie bliższej współpracy między Japonią a ChRL nie było pozbawione szans powodzenia. Niczym w trójkącie równobocznym, Japonia miała zachować taki sam dystans w relacjach z Chinami, jak z USA.

Hatoyama Yukio już w latach 90. XX wieku uważał, iż Japonia nadmiernie ulega presji ze strony Stanów Zjednoczonych i powinna położyć większy nacisk na kontakty z bliższymi jej pod względem historycznym i kulturowym

7 N. Kishi, Kishi Nobusuke kaikoroku - Hoshu gōdō to anpo kaitei [Pamiętnik Kishiego Nobusuke - Fuzja konserwatywna i rewizja traktatu o zapewnieniu bezpieczeństwa], Tokio 1983, s. 198-331, 637. 
Chinami. Jak przyznawał, swoje przekonania odziedziczył po dziadku i jego idei „braterstwa” (yūai), czyli koncepcji łączącej zalety dwóch wartości: „samodzielności” (jiritsu) i „symbiozy” (kyōsei). Oznaczała ona konieczność zachowania pełnej niezależności w polityce zagranicznej przy jednoczesnym poszanowaniu odmienności kulturowej, gospodarczej czy politycznej innych społeczeństw. Hatoyama Yukio rozbudował ową ideę, głosząc potrzebę prowadzenia bardziej samodzielnej polityki wobec USA oraz stworzenia azjatyckiej wersji Unii Europejskiej.

Hatoyama zachowywał dystans wobec Stanów Zjednoczonych nie tylko $\mathrm{w}$ sferze polityki bezpieczeństwa, ale również polityki gospodarczej. Tuż przed zwycięskimi dla PD wyborami parlamentarnymi pod koniec sierpnia 2009 roku opublikował artykuł w „The New York Times”, w którym wyraził zaniepokojenie "rynkowym fundamentalizmem” narzucanym przez USA w ramach globalizacji. Hatoyama przekonywał, że postawa „braterstwa” wymaga położenia większego nacisku na poszanowanie lokalnych tradycji ekonomicznych, kultur i stylów życia oraz odbudowy instytucji zaufania publicznego. Twierdził, iż z powodu słabnięcia gospodarki amerykańskiej w związku z kryzysem finansowym świat coraz wyraźniej odchodzi od porządku jednobiegunowego i lawiruje w kierunku multilateralizmu. Według Hatoyamy, o ile sojusz z USA pozostanie podstawą polityki bezpieczeństwa Japonii, o tyle rząd w Tokio powinien wypracować niezależną postawę pomiędzy dwiema potęgami - Stanami Zjednoczonymi i Chinami. W tym celu proponował nasilenie konstruktywnego dialogu z ChRL i Koreą Południową, zaś w dalszej perspektywie budowę Wspólnoty Wschodnioazjatyckiej i wprowadzenie wspólnej waluty z państwami ościennymi.

Sekretarz generalny PD Ozawa Ichirō miał podobne poglądy. Kiedy w 1993 roku opuścił PL-D, postulował uczynienie z Japonii „,normalnego kraju”, który sprawnie dostosuje się do realiów pozimnowojennych. W swoim bestsellerze „Plan przebudowy Japonii” podkreślał, że rząd w Tokio nie może dłużej zrzucać całego ciężaru zapewnienia bezpieczeństwa w regionie Azji Wschodniej na Stany Zjednoczone. Ozawa zwracał uwagę na fakt, że nawet sam Yoshida Shigeru twierdził, iż po odbudowie gospodarczej kraju z wojennej pożogi Japonia powinna przestać polegać jedynie na potędze USA i zacząć prowadzić bardziej samodzielną politykę zagraniczną. Z drugiej strony, szansę na odegranie

8 Y. Hatoyama, Shin kenpō shian. Songen aru Nihon o tsukuru [Szkic nowej konstytucji. Ku stworzeniu godnej Japonii], Tokio 2005, s. 4-18.

9 Idem, A New Path for Japan, „The New York Times”, 26.08.2009, http://www.nytimes. com/2009/08/27/opinion/27iht-edhatoyama.html?_r=0 (dostęp: 19.02.2016). 
przez Japonię większej roli w utrzymaniu pokoju na świecie Ozawa nadal upatrywał we współpracy ze Stanami Zjednoczonymi, zaś Chiny postrzegał raczej jako zagrożenie dla stabilności w regionie. Oczekiwał jednak od USA porzucenia roli „światowego żandarma” i zwrotu ku polityce bezpieczeństwa opartej na multilateralizmie w ramach systemu Narodów Zjednoczonych ${ }^{10}$.

Od kiedy Ozawa wstąpił do PD w 2003 roku, zaczął coraz krytyczniej wypowiadać się na temat sojuszu ze Stanami Zjednoczonymi i jednocześnie szukać zbliżenia z rządem w Pekinie. Ostro krytykował premiera Koizumiego Jun'ichirō za pomoc logistyczną udzieloną flocie USA w trakcie operacji w Afganistanie w 2001 roku oraz za wysłanie Sił Samoobrony do Iraku w 2004 roku. Ozawa twierdził, że takie bezwzględne podążanie za Stanami Zjednoczonymi było dowodem na nadmierną podległość wobec USA i brak posiadania szerszej strategii działania przez rząd w Tokio. Uważał, iż władze w Waszyngtonie naruszyły wzajemne zaufanie w relacjach bilateralnych, naciskając na uczestnictwo Japonii w przedsięwzięciach, które nie zawsze były autoryzowane przez $\mathrm{ONZ}{ }^{11}$. W trakcie rozmów $\mathrm{z}$ amerykańską sekretarz stanu Hillary Clinton w lutym 2009 roku zauważył nawet, że siły USA w Japonii mogłyby być ograniczone do samej Siódmej Floty ${ }^{12}$. Jednocześnie, od czasu rządów Koizumiego (2001-2006) Ozawa regularnie organizował zakrojone na szeroką skalę wizyty parlamentarzystów z PD w ChRL. Jak podkreślił, o ile Japonia powinna kontynuować bliską współpracę z USA, o tyle wzmocnienie kontaktów Japonii z Chinami stanowiło klucz do utrzymania pokoju w Azji Wschodniej. Ozawa doszedł do przekonania, że tylko szczery dialog z przywódcami ChRL umożliwi przełamanie problemów we wzajemnych kontaktach i lepsze zrozumienie drugiej strony ${ }^{13}$.

Po zmianie władzy liderzy PD szybko przystąpili do realizacji nowej wizji polityki zagranicznej. Już we wrześniu 2009 roku Hatoyama wyłożył podstawy własnej linii dyplomatycznej w trakcie posiedzenia Zgromadzenia Ogólnego ONZ w Nowym Jorku. Odwołując się do spuścizny swojego dziadka zauważył, że Japonia powinna odgrywać rolę pomostu „pomiędzy Wschodem a Zachodem, między krajami rozwiniętymi i rozwijającymi się oraz między

10 I. Ozawa, Nihon kaizō keikaku [Plan przebudowy Japonii], Tokio 2006, s. 102-118.

11 Idem, Ozawaizumu. Kokorozashi o mote, Nihonjin [Ozawaizm. Miejcie ambicję, Japończycy], Tokio 2009, s. 144-149.

12 Ch. W. Hughes, The Democratic Party of Japan's New (but Failing) Grand Security Strategy. From „Reluctant Realism” to „Resentful Realism”?, [w:] Japan under the DPJ: The Politics of Transition and Governance, K. E. Kushidy, Ph. Y. Lipscy (red.), Stanford 2013, s. 343.

13 I. Ozawa, Gōwan ishin [Mocarna odnowa], Tokio 2006, s. 140-213. 
różnymi cywilizacjami”" ${ }^{14}$. Na szczycie przywódców Japonii, Chin i Korei Południowej w Pekinie w październiku 2009 roku Hatoyama powtórzył, iż Japonia w przeszłości nadmiernie polegała na Stanach Zjednoczonych i że PD pragnie zwrócić się w stronę Azji ${ }^{15}$. Za słowami szły konkretne działania mające na celu demonstrację samodzielności Japonii wobec Stanów Zjednoczonych. Władze w Tokio zdecydowały o nieprzedłużeniu operacji wsparcia logistycznego dla sił USA na Oceanie Indyjskim, która tym samym dobiegła końca w styczniu 2010 roku. Z kolei minister spraw zagranicznych Okada Katsuya rozkazał przeprowadzenie śledztwa, które ujawniło, że za rządów PL-D Japonia zawarła ze Stanami Zjednoczonymi tajne porozumienie umożliwiające Amerykanom sprowadzanie broni nuklearnej do Kraju Kwitnącej Wiśni ${ }^{16}$.

Równolegle Ozawa aktywnie działał na rzecz zbliżenia z Chinami. Pod koniec listopada 2009 roku wywarł nacisk na Agencję Dworu Cesarskiego, aby doprowadzić do spotkania między cesarzem Akihito a wiceprzewodniczącym ChRL Xi Jinpingiem w grudniu 2009 roku bez zachowania niepisanej reguły ustalania takich wizyt $\mathrm{z}$ miesięcznym wyprzedzeniem. W grudniu 2009 roku Ozawa odwiedził Chiny na czele delegacji liczącej aż 640 członków, w tym 143 parlamentarzystów z PD. Każdego z nich z osobna przedstawił przewodniczącemu Hu Jintao ${ }^{17}$.

Ostatecznie, jednak, Hatoyama i Ozawa nie byli w stanie dokonać generalnej redefinicji linii dyplomatycznej Japonii. Proamerykańsko nastawieni biurokraci z Ministerstwa Spraw Zagranicznych nie tylko nie sprzyjali planom premiera, ale wręcz sabotowali przedsięwzięcia, które mogłyby naruszyć status quo w sojuszu ze Stanami Zjednoczonymi. W trakcie kampanii wyborczej w 2009 roku Hatoyama obiecał, że doprowadzi do relokacji amerykańskiej bazy wojskowej Futenma z zatłoczonego miasta Ginowan na Okinawie poza prefekturę. Miało to na celu złagodzić ciężar, jaki dla miejscowej ludności stanowiło stacjonowanie na Okinawie gros amerykańskich sił zbrojnych w Japonii. Spełnienie obietnicy wyborczej wymagało jednak renegocjacji umowy z USA z 2006 roku, która zakładała przenosiny Futenmy

14 Permanent Mission of Japan to the United Nations, New York, Address by H. E. Droku Yukio Hatoyama, Prime Minister of Japan at the Sixty-Fourth Session of the General Assembly of the United Nations, 24.09.2009, New York, http://www.un.org/ga/64/ generaldebate/pdf/JP_en.pdf (dostęp: 14.02.2016).

15 D. Sneider, The New Asianism: Japanese Foreign Policy under the Democratic Party of Japan, [w:] Japan under the DPJ..., s. 394.

16 Ch. W. Hughes, op. cit., s. 341-346.

17 K. Żakowski, Decision-Making Reform in Japan: The DPJ's Failed Attempt at a Politician-Led Government, London-New York 2015, s. 85-86. 
na wybrzeże Henoko na Okinawie. Pomimo licznych rozmów ze stroną amerykańską, rząd w Tokio nie był w stanie przekonać administracji Baracka Obamy do kompromisu. Ostatecznie w maju 2010 roku Hatoyama musiał potwierdzić umowę z 2006 roku, zaś w następnym miesiącu podał się do dymisji ${ }^{18}$. W związku ze wzrostem napięcia w relacjach chińsko-japońskich po incydencie na Morzu Wschodniochińskim z września 2010 roku, następcy Hatoyamy na fotelu premiera, Kan Naoto i Noda Yoshihiko, powrócili do koncepcji ścisłego sojuszu ze Stanami Zjednoczonymi ${ }^{19}$.

\section{USA i Chiny w polityce premiera Abe Shinzō}

W grudniu 2012 roku PL-D ponownie sformowała rząd na czele z premierem Abe Shinzō, wnukiem premiera Kishiego Nobusuke. Abe podzielał zdanie Ozawy i Hatoyamy, że Japonia powinna prowadzić bardziej aktywną politykę zagraniczną, ale nie postrzegał Chin jako potencjalnej przeciwwagi dla wpływów amerykańskich. Wręcz przeciwnie, podobnie jak dziadek w latach 50. XX wieku, Abe był nacjonalistą i zdeklarowanym antykomunistą. $\mathrm{Z}$ tego powodu nasilił starania w celu zacieśnienia sojuszu z USA, aby przeciwdziałać zagrożeniu ze strony ChRL.

Jeszcze jako wicesekretarz gabinetu (zaś w latach 2003-2004 sekretarz generalny PL-D i w latach 2005-2006 sekretarz gabinetu) w rządzie Koizumiego, Abe zdecydowanie poparł decyzje premiera o pomocy logistycznej dla wojsk USA na Morzu Indyjskim w trakcie operacji w Afganistanie po zamachach 11 września 2001 roku oraz o wysłaniu Sił Samoobrony do okupowanego Iraku w 2004 roku. Jak podkreślał, utrzymanie „sojuszu krwi” z USA było dla Japonii sprawą „życia lub śmierci”. Abe zdecydowanie krytykował oficjalną interpretację konstytucji, zgodnie z którą Japonia nie mogła uczestniczyć w paktach samoobrony zbiorowej. Sądzil, że jest naturalnym, iż należy przypieczętować sojusz gotowością do „przelania krwi” za Amerykanów w razie ataku na USA

18 Ibidem, s. 97-104.

19 We wrześniu 2010 roku chiński kuter rybacki zderzył się z okrętem patrolowym Japońskiej Straży Przybrzeżnej w pobliżu wysp Senkaku/Diaoyutai - bezludnego archipelagu administrowanego przez Japonię, do którego roszczenia wysuwa rząd w Pekinie. Aby zmusić Japonię do uwolnienia aresztowanego kapitana kutra, Chiny zastosowały liczne kontrowersyjne narzędzia nacisku, takie jak wstrzymanie eksportu metali ziem rzadkich czy zatrzymanie w prowincji Hebei czterech japońskich obywateli podejrzanych o szpiegostwo. Władze w Tokio ostatecznie wypuściły chińskiego kapitana, ale w międzyczasie doszło do serii gwałtownych demonstracji antyjapońskich w wielu chińskich miastach (przyp. autora). 
ze strony kraju trzeciego ${ }^{20}$. Abe podkreślał, że Stany Zjednoczone łączą z Japonią nie tylko wspólne interesy, ale również wspólne wartości, takie jak wolność, demokracja, rządy prawa czy gospodarka rynkowa. Na temat Chin, z kolei, wypowiadał się z dużą rezerwą. $Z$ jednej strony zauważał konieczność rozwoju bilateralnej wymiany handlowej, z drugiej zaś krytykował władze w Pekinie za propagowanie uczuć antyjapońskich. W relacjach z Chinami Abe promował ideę rozdziału polityki od gospodarki, aby uniemożliwić ChRL używania sankcji ekonomicznych do wywierania presji na Japonię ${ }^{21}$. Bardzo negatywnie wypowiadał się przy tym o postępowaniu propekińsko nastawionych frakcji wywodzących się ze szkoły Yoshidy w PL-D. Twierdził, iż przyjaźni z Chinami nie należy utrzymywać za wszelką cenę, gdyż naczelnym celem powinna być realizacja interesów narodowych Japonii ${ }^{22}$.

O ile za swojej pierwszej kadencji jako premier w latach 2006-2007 Abe doprowadził do nagłego zbliżenia $\mathrm{z}$ Chinami dzięki powstrzymaniu się od wizyty w kontrowersyjnej świątyni Yasukuni w Tokio, o tyle po 2012 roku nie był skłonny do żadnych ustępstw w relacjach z $\mathrm{ChRL}^{23}$. Powodem usztywnienia nastawienia wobec władz w Pekinie była eskalacja napięcia w związku ze sporem o wyspy Senkaku/Diaoyutai ${ }^{24}$. Abe uważał, że kwestie terytorialne, jako związane z żywotnymi interesami narodowymi, nie powinny być przedmiotem jakichkolwiek negocjacji. Jak podkreślił, owe bezludne wyspy nie mogą być obronione poprzez rozmowy, ale tylko poprzez „siłę fizyczną”. Swoje słowa Abe potwierdził zwiększając budżety Ministerstwa Obrony i Japońskiej

20 S. Abe, H. Okazaki, Kono kuni o mamoru ketsui [Determinacja obrony tego kraju], Tokio 2004, s. 56-63.

S. Abe, Utsukushii kuni e [Ku pięknemu krajowi], Tokio 2006, s. 129-156.

S. Abe, H. Okazaki, op. cit., s. 161.

Świątynia Yasukuni upamiętnia wszystkich Japończyków, którzy polegli w służbie ojczyzny. W 1978 roku na listę czczonych w niej dusz wpisano również nazwiska zbrodniarzy wojennych klasy A skazanych na śmierć po II wojnie światowej. Z tego powodu od 1985 roku Chiny zdecydowanie protestowały przeciw wizytom w świątyni japońskich premierów. W latach 2001-2006 Yasukuni była corocznie odwiedzana przez premiera Koizumiego Jun'ichirō, co doprowadziło do znacznego ochłodzenia stosunków japońsko-chińskich.

24 W kwietniu 2012 roku gubernator Tokio Ishihara Shintarō zapowiedział zakup przez okręg stołeczny od prywatnego właściciela trzech wysp spornego z Chinami archipelagu Senkaku/Diaoyutai. Deklaracja ta skłoniła premiera Nodę Yoshihiko do nacjonalizacji wysp we wrześniu 2012 roku. Owo posunięcie spotkało się ze zdecydowanym protestem ze strony władz w Pekinie i wywołało serię pełnych przemocy demonstracji antyjapońskich w ChRL. Od tego czasu chińskie statki badawcze i okręty wojenne zaczęły regularnie naruszać japońską wyłączną strefę ekonomiczną i wody terytorialne (przyp. autora). 
Straży Przybrzeżnej ${ }^{25}$. Z kolei w styczniu 2013 roku premier Japonii ogłosił „pięć nowych zasad dyplomacji Japonii”, wśród których czołowe miejsce zajmowała ochrona takich zachodnich wartości, jak wolność słowa, liberalizm gospodarczy czy prawo morza ${ }^{26}$. Nietrudno było się w tym dopatrzeć odpowiedzi na prowokacyjne naruszanie japońskich wód przez chińskie statki badawcze, a nawet okręty wojenne. Równie istotną przeszkodą w przełamaniu impasu w relacjach Japonii z Chinami były problemy historyczne. Stosunki bilateralne uległy szczególnemu pogorszeniu po wizycie Abe w świątyni Yasukuni w grudniu 2013 roku. W 2014 roku oba kraje uwikłały się w prawdziwą „wojnę propagandową", starając się przekonać do swoich argumentów na temat problemów historycznych i sporu terytorialnego opinię publiczną w państwach trzecich, zwłaszcza w Europie i Ameryce Północnej ${ }^{27}$.

Jako przeciwwagę dla rosnącej potęgi Chin premier Japonii postrzegał ścisłą współpracę rządu w Tokio z krajami demokratycznymi w regionie Azji-Pacyfiku na czele ze Stanami Zjednoczonymi. Abe zdecydowanie krytykował PD, oskarżając ją o snucie nierealistycznych wizji zbliżenia z Chinami, które poważnie naruszyły wzajemne zaufanie w kontaktach z USA ${ }^{28}$. Zamiast kontynuować inicjatywę stworzenia Wspólnoty Wschodnioazjatyckiej, tuż po powrocie do władzy przedstawił koncepcję „demokratycznego diamentu bezpieczeństwa Azji”. Obejmował on Japonię, Indie, Australię oraz Stany Zjednoczone reprezentowane w regionie przez Hawaje. Według Abe, te cztery kraje powinny koordynować działania, aby zapewnić bezpieczeństwo na wodach Oceanu Indyjskiego i zachodniego Pacyfiku ${ }^{29}$. Nie sposób nie dopatrzeć się w owej propozycji planów stworzenia „kordonu sanitarnego” wokół Chin.

Środkiem do wzmocnienia sojuszu z USA było nie tylko podkreślanie przywiązania Japonii do zachodnich wartości, ale przede wszystkim gruntowna rewizja polityki bezpieczeństwa. W 2013 roku Abe przyjął narodową

25 S. Abe, Atarashii kuni e. Utsukushii kuni e. Kanzenban [Ku nowemu krajowi. Ku pięknemu krajowi. Pełne wydanie], Tokio 2013, s. 248-249.

26 The Bounty of the Open Seas: Five New Principles for Japanese Diplomacy, Address by H. E. Mr. Shinzo Abe, Prime Minister of Japan, January 18, 2013, Jakarta, Ministry of Foreign Affairs of Japan, http://www.mofa.go.jp/announce/pm/abe/abe_0118e.html (dostęp: 31.07.2015).

27 Yomiuri Shinbun Seijibu, „Nicchūkan” gaikō sensō. Nihon ga chokumen suru „ima soko ni aru kiki” [Wojna dyplomatyczna „między Japonią, Chinami i Koreą Południową”. Kryzys, któremu Japonia stawia czoła „tu i teraz”], Tokio 2014, s. 20-142. S. Abe, Atarashii kuni e..., s. 246-247.

29 Idem, Asia's Democratic Security Diamond, „Project Syndicate”, 27.12.2012, http:// www.project-syndicate.org/print/a-strategic-alliance-for-japan-and-india-by-shinzo-abe (dostęp: 31.07.2015). 
strategię bezpieczeństwa, w której położył nacisk na zwiększenie zdolności odstraszania, zacieśnienie współpracy wojskowej z USA oraz odgrywanie przewodniej roli $\mathrm{w}$ rozwiązywaniu konfliktów międzynarodowych. Nowa doktryna została nazwana „aktywnym pacyfizmem” (sekkyokuteki heiwashugi). W celu umożliwienia sprawniejszej wymiany informacji wywiadowczych z USA równolegle przegłosowano kontrowersyjną ustawę, która zaostrzyła kary za ujawnienie tajemnic państwowych. Z kolei aby przyspieszyć proces decyzyjny w sytuacjach kryzysowych powołano do życia Radę Bezpieczeństwa Narodowego (Kokka Anzen Hoshō Kaigi) ${ }^{30}$.

Kluczem do modyfikacji wytycznych sojuszu ze Stanami Zjednoczonymi było przezwyciężenie ograniczeń konstytucyjnych. Zgodnie z oficjalną interpretacją konstytucji, pomimo zrzeczenia się w artykule 9 prawa do prowadzenia wojny i posiadania jakiegokolwiek potencjału militarnego, Japonia zachowała prawo do samoobrony. Z drugiej strony, Biuro Legislacyjne Gabinetu utrzymywało, że konstytucja zabrania uczestnictwa Japonii w paktach samoobrony zbiorowej. Premier Abe wymienił dyrektora tego kluczowego organu na podzielającego jego poglądy biurokratę z Ministerstwa Spraw Zagranicznych, co otworzyło drogę do rewolucyjnej zmiany interpretacji konstytucji. Zgodnie z decyzją gabinetową z lipca 2014 roku, Japonia uzyskała prawo do samoobrony nie tylko w przypadku bezpośredniego ataku na jej terytorium, ale również w razie wystąpienia zbrojnej inwazji przeciw „zagranicznemu krajowi pozostającemu w bliskich relacjach z Japonią," która w rezultacie „zagraża przetrwaniu Japonii” i stwarza wyraźne zagrożenie dla „prawa narodu do życia, wolności i poszukiwania szczęścia”’31. Tak szeroka interpretacja prawa do samoobrony oznaczała, że rząd w Tokio po raz pierwszy przyznał, iż przyjdzie z pomocą Stanom Zjednoczonym w przypadku agresji na ich terytorium przez państwo trzecie.

Ostatnim etapem procesu zacieśniania sojuszu było wydanie jego nowych wytycznych w kwietniu 2015 roku. Zgodnie z poprzednimi wytycznymi z 1997 roku Japonia zobowiązała się do wsparcia logistycznego wojsk amerykańskich „w sytuacjach w strefach otaczających Japonię, które będą miały istotny wpływ na pokój i bezpieczeństwo Japonii”32. Nowe wytyczne zniosły owo geograficzne ograniczenie zasięgu współpracy, zaznaczając, że oba

30 K. Żakowski, Od „twórczej dyplomacji” do „aktywnego pacyfizmu”: Ewolucja koncepcji polityki zagranicznej Japonii, „Sprawy Międzynarodowe” 2015, nr 3, s. 120-122.

31 Cabinet Decision on Development of Seamless Security Legislation to Ensure Japan's Survival and Protect its People, Ministry of Foreign Affairs of Japan, 01.07.2014, http://www.mofa.go.jp/fp/nsp/page23e_000273.html (dostęp: 26.02.2016).

32 The Guidelines for Japan-U.S. Defense Cooperation, Ministry of Defense, 23.09.1997, http://www.mod.go.jp/e/d_act/anpo/19970923.html (dostęp: 27.02.2016). 
kraje będą "promować stabilny, pokojowy i zamożny region Azji-Pacyfiku i nie tylko". To sformułowanie wskazuje, że sojusz uzyskał zasięg globalny. Na dodatek, w nowych wytycznych nie tylko powtórzono nową interpretację konstytucji dającą Japonii prawo do uczestnictwa w paktach samoobrony zbiorowej, ale również wyraźnie stwierdzono, że oba kraje będą wspólnie rozwijać technologie wojskowe i produkować bron' ${ }^{33}$.

\section{Krytyka nadmiernego ochłodzenia relacji z ChRL}

Zacieśnienie sojuszu z USA kosztem relacji z Chinami wywołało reakcję obozu umiarkowanych polityków z PL-D. Wielu parlamentarzystów starszego pokolenia nadal czuło przywiązanie do doktryny Yoshidy i nie rozumiało, czemu utrzymanie wyraźnie proamerykańskiej postawy ma skazywać Japonię na wejście na kurs kolizyjny z ChRL. Szczególnie aktywni w krytykowaniu dyplomacji w wykonaniu premiera Abe okazali się dawniej wpływowi politycy z nurtu Yoshidy, którzy kilka lat wcześniej przeszli na emerytury. W forpoczcie owego ruchu stanęli m.in. były przewodniczący PL-D, wicepremier w latach 1994-1995 i minister spraw zagranicznych w latach 1994-1996 i 1999-2001 Kōno Yōhei oraz były sekretarz gabinetu w latach 1998-1999 Nonaka Hiromu.

Kōno Yōhei jest synem Kōno Ichirō, lidera dawnej frakcji Hatoyamy Ichirō. Mimo to, z przyczyn ideologicznych w latach 80. XX wieku nie związał się z wywodzącą się z grupy ojca frakcją Nakasone, a z frakcją jednego z uczniów Yoshidy, Miyazawy Kiichiego ${ }^{34}$. Co charakterystyczne dla owego nurtu, Kōno łączył zdecydowany proamerykanizm z umiarkowanie propekińską postawą. Były mu bliskie idee stworzenia Wspólnoty Wschodnioazjatyckiej, ale krytykował premiera Hatoyamę Yukio za niedostateczne przygotowanie owej rewolucyjnej koncepcji. Jak podkreślał, tak przełomowy projekt mógł być zrealizowany jedynie po wyczerpujących negocjacjach i uzyskaniu zgody ze strony Stanów Zjednoczonych ${ }^{35}$.

Odpowiadając na asertywną politykę premiera Abe, z kolei, Kōno przekonywał, że nie należy Chin apriorycznie uznawać za zagrożenie jedynie $\mathrm{z}$ tego powodu, że rozbudowują swój potencjał militarny. Zapytywał, czemu Japonia ma traktować jako groźbę dla własnego bezpieczeństwa broń

33 The Guidelines for Japan-U.S. Defense Cooperation, Ministry of Defense, 27.04.2015, http://www.mod.go.jp/e/d_act/anpo/shishin_20150427e.html (dostęp: 27.02.2016).

34 Wywiad autora z Kōno Yōheiem, Tokio, 13 marca 2009 roku.

35 Wywiad autora z Kōno Yōheiem, Tokio, 20 czerwca 2013 roku. 
nuklearną czy lotniskowce ChRL, podczas gdy analogiczny potencjał militarny USA nie budzi zastrzeżeń. Według Kōno, Chiny podobnie jak Stany Zjednoczone nie mają agresywnych zamiarów wobec Japonii, zaś poczucie zagrożenia z ich strony wynika bardziej z subiektywnych działań rządu w Tokio niż z obiektywnych uwarunkowań międzynarodowych. Wszakże wróg zewnętrzny potrzebny jest japońskim populistom w celu utrzymania wysokiego poparcia społecznego oraz uzasadnienia takich działań, jak zmiana interpretacji konstytucji czy wzrost wydatków na obronność. Zdaniem Kōno, jedynym racjonalnym rozwiązaniem sporu z Chinami nie jest występowanie z pozycji siły, ale intensyfikacja konstruktywnego dialogu w celu przywrócenia wzajemnego zaufania ${ }^{36}$.

Kōno Yōhei wyrażał zaniepokojenie polityką zagraniczną rządu Abe. Nie mógł zrozumieć, w jaki sposób Abe mógł nazwać swoją linię dyplomatyczną „aktywnym pacyfizmem”. Wszakże według Kōno pacyfizm oznacza utrzymanie takich uregulowań, jak zakaz eksportu broni czy artykuł 9 konstytucji. Dążenie do dekompozycji owego systemu, które prowadzi do destabilizacji sytuacji międzynarodowej $\mathrm{w}$ regionie, uważał za działanie przeciwstawne duchowi pacyfizmu. Zdaniem Kōno, środkiem do przezwyciężenia tej sytuacji powinno być zbliżenie do Chin i Korei Południowej, np. poprzez członkostwo w Azjatyckim Banku Inwestycji Infrastrukturalnych, utworzonym z inicjatywy ChRL. Jednocześnie Kōno nie zamierzał rezygnować z wyraźnie proamerykańskiej polityki w duchu doktryny Yoshidy. Podkreślał, że tak naprawdę Stanom Zjednoczonym nie zależało na narzucaniu siłą rządowi w Tokio zmiany interpretacji konstytucji, aby umożliwić uczestnictwo Japonii w paktach samoobrony zbiorowej. Jak argumentował, wielu polityków Partii Demokratycznej w USA z niepokojem obserwowało takie prawicowe przedsięwzięcia Abe, jak wizyta w świątyni Yasukuni, które burzyły porządek powojenny. Według Kōno, władzom w Waszyngtonie zależało głównie na utrzymaniu stabilnej sytuacji w Azji Wschodniej, a temu nie służyły niesnaski między Japonią a Chinami czy Koreą Południową ${ }^{37}$.

Podobnie jak Kōno, Nonaka Hiromu był związany z nurtem Yoshidy, choć $\mathrm{z}$ inną frakcją - dawną grupą Tanaki Kakueia, który jako premier nawiązał oficjalne relacje dyplomatyczne z ChRL w 1972 roku. W czerwcu 2013 roku Nonaka odwiedził Pekin, gdzie wywołał prawdziwą sensację przyznając, że Tanaka powiedział mu przed laty, iż zgodził się na zawieszenie sporu

36 Y. Kōno, Nihon gaikō e no chokugen - Kaisō to teigen [Szczera rozmowa o dyplomacji Japonii - Wspomnienia i sugestie], Tokio 2015, s. 11, 211.

37 Ibidem, s. 181-187. 
terytorialnego o wyspy Senkaku/Diaoyutai. Oświadczenie to stało w sprzeczności ze stanowiskiem japońskiego Ministerstwa Spraw Zagranicznych, które utrzymywało, że Japonia nigdy nie przyznała, iż istnieje jakikolwiek spór terytorialny z Chinami. Po powrocie z Pekinu Nonaka zaapelował o porozumienie z Chinami podkreślając, że polityka konfrontacji z ChRL prowadzona przez premiera Abe jest niezgodna $\mathrm{z}$ japońskim interesem narodowym ${ }^{38}$.

Dawny obóz Yoshidy był jednak zbyt słaby, by wpłynąć na politykę rządu. Nawet minister spraw zagranicznych Kishida Fumio, który wywodził się $\mathrm{z}$ owego nurtu, odgrywał drugorzędną rolę w formułowaniu linii dyplomatycznej Japonii. Dzięki wysokiemu poparciu społecznemu dla polityki gospodarczej i finansowej rządu, premier Abe zdołał uśmierzyć głosy niezadowolenia ze swoich nacjonalistycznych przedsięwzięć, które co jakiś czas dało się słyszeć ze strony umiarkowanych posłów PL-D.

\section{Podsumowanie}

Przegląd stanowisk japońskich polityków na temat relacji ze Stanami Zjednoczonymi i Chinami wskazuje na brak kompromisu pośród japońskiego establishmentu politycznego odnośnie do strategii dyplomatycznej wobec narastającej dwubiegunowości na poziomie globalnym i regionalnym. O ile dla wszystkich polityków z obozu konserwatywnego sojusz z USA stanowił filar bezpieczeństwa Japonii, o tyle istniały różnorodne opinie na temat preferowanej skali zaangażowania Japonii w przedsięwzięcia Stanów Zjednoczonych. Podczas gdy proamerykańscy liberałowie i proamerykańscy nacjonaliści dokładali wszelkich starań, aby nie narażać na szwank stosunków z władzami w Waszyngtonie, zwolennicy multilateralizmu stawiali wyraźniejsze warunki globalnemu supermocarstwu. Dla jednych sojusz z USA nie mógł stać na przeszkodzie przed integracją regionalną w Azji Wschodniej, dla innych zaś powinien być osadzony w bardziej obiektywnych ramach systemu ONZ. Kolejna oś podziału dotyczyła relacji z Chinami. O ile proazjatyccy multilateraliści i proamerykańscy liberałowie starali się zaangażować ChRL w jak najdalej idącą współpracę, aby wzmacniać wzajemne zaufanie w relacjach bilateralnych, o tyle bardziej prawicowe środowiska wyrażały sceptycyzm wobec prób pozyskania przyjaźni władz w Pekinie za wszelką cenę.

38 K. Kosaka, R. Kuratomi, N. Hayashi, „Senkaku tanaage, kokkō seijōka toki ni kakunin”: Seifu, Nonaka moto kanbōchōkan no hatsugen hikeshi [„Potwierdzenie zawieszenia Senkaku podczas normalizacji stosunków”: Rząd gasi wypowiedź byłego sekretarza gabinetu Nonaki], „Asahi Shinbun”, 05.06.2013, wydanie poranne, s. 3. 
Co ciekawe, poszczególne nurty w obozie konserwatywnym były relatywnie trwałe. Często, choć nie zawsze, poglądy polityczne na temat stosunków z USA i Chinami były przekazywane jako tradycja rodzinna z pokolenia na pokolenie. Najlepszymi przykładami było manifestowanie przez Hatoyamę Yukio i Abe Shinzō przywiązania do spuścizny ich wielkich dziadków. W tym kontekście można stwierdzić, że obok ewolucji sytuacji międzynarodowej nastawienie Japonii do narastającej koncepcji dwubiegunowości w dużym stopniu zależało od tego, który z nurtów sprawował władzę w danym czasie. Biorąc to pod uwagę, nie jest wykluczone że obecna strategia zacieśniania sojuszu z USA celem powstrzymywania Chin może ulec daleko idącym zmianom $w$ razie zastąpienia premiera Abe przez innego polityka, nawet jeśli będzie on pochodził $z$ tej samej partii.

\section{Bibliografia}

ABE S., Asia's Democratic Security Diamond, „Project Syndicate”, 27.12.2012, http://www.project-syndicate.org/print/a-strategic-alliance-for-japan -and-india-by-shinzo-abe.

ABE S., Atarashii kuni e. Utsukushii kuni e. Kanzenban [Ku nowemu krajowi. Ku pięknemu krajowi. Pełne wydanie], Tokio 2013.

ABE S., Utsukushii kuni e [Ku pięknemu krajowi], Tokio 2006.

ABE S., OKAZAKI, H., Kono kuni o mamoru ketsui [Determinacja obrony tego kraju], Tokio 2004.

CABINET Decision on Development of Seamless Security Legislation to Ensure Japan's Survival and Protect its People, 01.07.2014, http://www.mofa.go.jp/ $\mathrm{fp} / \mathrm{nsp} /$ page23e_000273.html.

THE Guidelines for Japan-U.S. Defense Cooperation, Ministry of Defense, 23.09.1997, http://www.mod.go.jp/e/d_act/anpo/19970923.html.

THE Guidelines for Japan-U.S. Defense Cooperation, Ministry of Defense, 27.04.2015, http://www.mod.go.jp/e/d_act/anpo/shishin_20150427e.html.

HATOYAMA I., Hatoyama Ichirō kaikoroku [Pamiętnik Hatoyamy Ichirō], Tokio 1957.

HATOYAMA Y., Shin kenpō shian. Songen aru Nihon o tsukuru [Szkic nowej konstytucji. Ku stworzeniu godnej Japonii], Tokio 2005.

HATOYAMA Y., A New Path for Japan, „The New York Times”, 26.08.2009, http:// www.nytimes.com/2009/08/27/opinion/27iht-edhatoyama.html?_r=0.

HUGHES Ch. W., The Democratic Party of Japan's New (but Failing) Grand Security Strategy. From „Reluctant Realism” to „Resentful Realism”?, [w:] 
Japan under the DPJ: The Politics of Transition and Governance, K. E. Kushidy, Ph. Y. Lipscy (red.), Stanford 2013.

KISHI N., Kishi Nobusuke kaikoroku - Hoshu gōdō to anpo kaitei [Pamiętnik Kishiego Nobusuke - Fuzja konserwatywna i rewizja traktatu o zapewnieniu bezpieczeństwa], Tokio 1983.

KŌNO Y., Nihon gaikō e no chokugen - Kaisō to teigen [Szczera rozmowa o dyplomacji Japonii - Wspomnienia i sugestie], Tokio 2015.

KOSAKA K., Kuratomi R., Hayashi N., „Senkaku tanaage, kokkō seijōka toki ni kakunin”: Seifu, Nonaka moto kanbōchōkan no hatsugen hikeshi [„Potwierdzenie zawieszenia Senkaku podczas normalizacji stosunków": Rząd gasi wypowiedź byłego sekretarza gabinetu Nonaki], „Asahi Shinbun”, 05.06.2013, wydanie poranne.

LIU D., Toki wa nagarete - Nitchū kankei hishi gojūnen [Czas przemija - 50 lat sekretnej historii stosunków japońsko-chińskich], t. 1, Tokio 2002.

MINISTRY of Foreign Affairs of Japan, The Bounty of the Open Seas: Five New Principles for Japanese Diplomacy, Dżakarta, 18.01.2013, http://www. mofa.go.jp/announce/pm/abe/abe_0118e.html.

OZAWA I., Gōwan ishin [Mocarna odnowa], Tokio 2006.

OZAWA I., Nihon kaizō keikaku [Plan przebudowy Japonii], Tokio 2006.

OZAWA I., Ozawaizumu. Kokorozashi o mote, Nihonjin [Ozawaizm. Miejcie ambicję, Japończycy], Tokio 2009.

PERMANENT Mission of Japan to the United Nations, Address by H. E. Droku Yukio Hatoyama Prime Minister of Japan at the Sixty-Fourth Session of the General Assembly of the United Nations, 24.09.2009, New York, http:// www.un.org/ga/64/generaldebate/pdf/JP_en.pdf.

SNEIDER D., The New Asianism: Japanese Foreign Policy under the Democratic Party of Japan, [w:] Japan under the DPJ: The Politics of Transition and Governance, K. E. Kushidy, Ph. Y. Lipscy (red.), Stanford 2013.

YOMIURI SHINBUN SEIJIBU, „Nicchükan” gaikō sensō. Nihon ga chokumen suru „ima soko ni aru kiki” [Wojna dyplomatyczna „między Japonią, Chinami i Koreą Południową”. Kryzys, któremu Japonia stawia czoła „tu i teraz”], Tokio 2014.

YOSHIDA S., Sekai to Nihon [Świat a Japonia], Tokio 1963.

YOSHIDA S., Kaisō jūnen [Wspomnienia z 10 lat], t. 1, Tokio 1998.

ŻAKOWSKI K., Decision-Making Reform in Japan: The DPJ's Failed Attempt at a Politician-Led Government, London-New York 2015.

ŻAKOWSKI K., Od „twórczej dyplomacji” do „aktywnego pacyfizmu”: Ewolucja koncepcji polityki zagranicznej Japonii, „Sprawy Międzynarodowe” 2015, nr 3. 